\title{
Perceived Benefits and Making a Career Choice in the Hospitality Industry: Is it Worth it?
}

\author{
Ruth Adhoch* \\ Department of Hotel and Hospitality Management, Alupe University College, P. O. Box 845-50400, Busia (K) \\ *Corresponding Author: Ruth Adhoch, Department of Hotel and Hospitality Management, Alupe \\ University College, P. O. Box 845-50400, Busia (K)
}

\begin{abstract}
Over the years, universities have continued to graduate students in the field of Hotel and Hospitality $(H \& H)$. However, existing statistics reveals that a majority of these graduates do not seek employment in the hospitality industry or start businesses in their area of study. This paper discusses the findings of a study which sought to establish the demographic factors influencing the attitudes of Hotel and Hospitality undergraduate students towards a career choice in the industry. The study was undertaken in Moi University, Department of Hotel and Hospitality Management, Uasin Gishu County, and Maseno University's Department of Ecotourism, Hotel and Institutional Management (ECOHIM) in Kisumu County and used a sample of 145 respondents. Data was collected using questionnaires and interview schedules and analyzed using SPSS ver. 25. The results intimated that perceived benefit had a positive and significant effect on career choice of the students in the industry $(\beta=0.013, \rho<0.05)$. Consequently, this paper posits that personal interests play a pivotal role in attitude formation. Most students view the industry as reputable and would have no qualms working in it. It was, however, noted that there are students who have less interest and harbour a negative attitude about the industry. This paper thus recommends that attention should be given to such students via career guidance and counselling. Educators should communicate the benefits of working in the industry and career possibilities in the hospitality industries and companies to students. They should make them aware about mobility progression, job diversity in the industry and other career information in order to create greater student interest about careers in the industry. Indeed knowledge of career identity and long term career planning will better enable students establish realistic and suitable career expectations.
\end{abstract}

Keywords: Perceived Benefits, Career, Hospitality Industry, Undergraduate Programmes, Attitudes.

\section{INTRODUCTION}

\subsection{Background}

The tourism and hospitality industry worldwide has been confronted with the problem of attracting and retaining quality employees. For example, according to the tourism trends in Canada, one of the challenges facing its tourism industry is regarded as the lack of adequate human resource strategies to attract and retain employees in the industry. This means that the industry does not have a strategy to ensure employee retention in the industry (Yin, 2014). Richardson (2008) explains that the tourism and hospitality industry worldwide has been confronted with the problem of attracting and retaining quality employees which has led to a shortage of skilled personnel to staff in the ever growing numbers of businesses. He further notes that, due to the fragmented nature of the industry, it is not well equipped to respond to the future challenges presented by the shortages and gaps in needed skills.

The hospitality industry is one with two inherent intellectual conflicts. By providing free hospitality to strangers, it is seen in all societies and cultures as a noble act yet the provision of hospitality for money is seen as somehow demeaning of the service provider. This raises a raft of issues in terms of recruiting and retaining high quality staff and providing them with meaningful enriching employment and career opportunities (Hill, 2013).

Jayaweera (2015) also reminds us that the industry strives, on one hand, for consistency of services and products which can readily be achieved with discipline and strict adherence to systems yet, on the other hand, it seeks to provide a form of personalized service that requires a relatively high level of discretion on the service provider. As a consequence, it is prudent that personal attributes play a major 
role as far as career progression and commitment to the industry is concerned. This therefore calls for a positive attitude in the students in order to have the drive and commitment as employees of the industry.

Studies on attitudes on tourism as a career have shown that students perceive the industry as having poor wages, low stability, poor working hours and working conditions (Chellen \& Nunkoo, 2010; Kim, McCleary, \& Kaufman, 2010; Richardson, 2010). As such, students pursuing studies in this field are the future face of the tourism and hospitality industry and therefore it is imperative to understand their employment intentions. Some evidence shows that students and graduates of tourism and hospitality programs have little or no intention of entering the industry upon graduation (Mohammed, 2018). Research has also demonstrated that promotion opportunity is one of the main factors that can influence students' intention to join the hospitality industry. In addition, physical working conditions and pay and benefits have an influence on students' intentions. Undergraduate students are usually unsure of their future career path, and many studies have found that their work experience in the hospitality industry identified few career promotion opportunities, with insufficient rewards for effort (Abdullah et al., 2015; Brown et al., 2014; Chang, Walsh \& Tse, 2014).

Focusing on the perceptions of the tourism industry and comparing the results of domestic versus international students in Australia, Richardson (2010) found that domestic students were decidedly more negative towards a career in the industry compared to international students Domestic students' qualms about a career in the industry were that factors they deemed important in a career were missing from the tourism industry. Students wanted job security, promotional prospects, increased earnings over their career, appropriate starting salary and a reasonable workload all of which domestic students did not believe the tourism industry could provide them.

In Mauritius, Chellen and Nunkoo (2010) found that over $80 \%$ of respondents were pleased to have chosen to study tourism and that they would like to work in the industry, with $61 \%$ of respondents not planning on working in any other industry. Also a study on tourism undergraduate perceptions in Turkey found that approximately $65 \%$ of respondents wanted to work in the industry once they had graduated and surprisingly a higher percentage $(76 \%)$ of respondents had work experience in the industry (Roney \& Öztin, 2007). Australian school-leavers were also interested in entering the management aspect of the industry (58\%), in particular those whose family or friends had already been employed in the industry.

Several researches have been done to describe careers from a variety of perspectives. According to Chang et al. (2014), career can be defined as the individual's perceived sequence of attitude and behaviour associated with work related experiences and activities over the span of a person's life. Whereas Meliou and Maroudas (2011) define it as a series of work related positions paid or unpaid that help a person grow in job skills, success and fulfilment; for Whitelaw, Barron, Buultjens, Cairncross and Davidson (2009), career is not static but has an evolutionary or progressive character, and is a form of continual investment through ones career; that it is a pattern even if of inconsistency in the career; that there is a pattern in the nature and types of jobs undertaken or roles played that form a career; that a career is one of the many roles that an individual fulfils and lastly that an individual is born with or acquires a set of skills, characteristics and attributes which are then developed and managed in order to advance ones career to achieve career success.

This backdrop helps enhance our understanding of the underlying nature of the career and its progression. It also enables this work identify the key elements of career choice that would help students within this industry. Considering that this paper is dealing with career choices, the above information is pertinent as it provides students with the knowledge to strategically make the right career choice and then appropriately manage their career progressions successfully.

Studies have indicated that emotional labour, coupled with excessive job demands and dysfunctional customer behaviours have a negative impact on student career choices (Hill, 2013; Mohammed, 2018). Emotional labour has been described as a process of regulating both feelings and expressions for organizational goals (ChooiHwa, Supinah, Japang, Rosie, \& Nasah, 2010). They are in fact controlled and managed in organizations by a wide range of formal and informal means (known as display values) ensuring that certain emotions are expressed and some are suppressed. This is a very worrying situation because employees are expected to conform to these expectations about emotional display even when they conflict with their inner feelings. 
ChooiHwa et al. (2010) continue to elaborate that emotional labour refers to the performance of various forms of work emotions in the context of paid employment. Various studies have indicated that emotional labour positively influences perception of service quality leading to a lot of gain for the establishment (Li, Canziani Barbieri, 2018). As much as this benefits the organization, it ignores the service provider who is the employee and in turn it may led to lack of job satisfaction, lack of organizational commitment and, certainly, emotional strain. Ghalandari, Jogh, Imani and Nia (2012) explain that much of hospitality work is based on profit maximization imperatives which include unquestioning subordination to the demands of customers almost totally ignoring the service providers' feelings. The above revelation informs this work well as part of the reasons why the hospitality industry may not be attractive to potential graduates.

Richardson (2008) did an exploratory study on perceptions and attitudes of undergraduate students in Australia and found that their main concern was their relationship with their managers, promotion, opportunities, career paths and pay and conditions offered within the industry. He observes that the most alarming finding is that more than $50 \%$ of respondents are already contemplating careers outside the industry and of those with work experience in the industry, $43.6 \%$ claim they will not work in the industry after graduation. He further cites that in Australia, factors impacting on shortage of skills in the industry include a high proportion of low skilled jobs, a large proportion of hours worked outside normal business hours, a negative industry image in the eyes of potential employees, poor utilization of student labour and high levels of staff turnover. These characteristics all add up to the complex problems that are associated with recruitment and retention in the industry.

The hospitality industry has been viewed as unattractive due to factors such as young transient work force, low pay, a perceived and real lack of formal qualification at all levels, high ratio of female workers, casual workers and a host of other factors. To put these factors into perspective, this paper looks at a model by Wasmley (2004), found in Jiang and Tribe (2009). This model which was specifically designed for tourism jobs, fits well in the hospitality sector which is compounded with the same issues and which is a component of tourism product. Wamsley called it "Tourism jobs: short lived profession". This model tends to bring out specific factors which influence attitudes towards working in the industry and in turn creating the unattractive nature of the industry to prospective employees. In this model, significant phenomenon is used in order to understand what attitudes tourism or hospitality students for this matter, hold and an understanding of the dimensions of such attitudes. The five conceptual categories examined by Wamsley are: personal reasons, nature of tourism jobs, human factors, educational factors and management factors.

Under the five categories, other sub categories emerged and summarized a range of factors that influenced students' vocational attitudes, and each of the five sub categories contained various dimensions: Personal reasons covered why students liked to follow tourism careers and these included personal traits, to be independent, capital collection, to broaden knowledge, and to relieve parents off some burden and dependence. Nature of the tourism jobs showed that the students had already obtained further understanding of tourism jobs through practical training. It raised issues about the tourism organization and the whole industry. It indicated that seasonality, instability, low skilled jobs, repetition, low income, and physical working environment all play a role in creating negative attitudes in students. Human factors influenced perceptions about relationships that develop in tourism employees and feelings about working in the sector. These (factors) included social relationship with tourists, saturation of the labour market, irregularity of the tourism market, and ways of making money.

These human factors were considered to have both positive and negative consequences on the attitudes of the students. Education factors included discussions about the effects of education and training in relation to tourism career experiences. They included practical training, education advantage and the curriculum. The students reported that the knowledge they acquired was appropriate and they in fact looked forward to working in the industry but were discouraged with the kind of treatment they received from the employers which made them to develop negative attitudes about working in the industry. Lastly, are the management factors comprising issues related to working inside tourism organizations, such as tourism operation mode, mechanisms of employment and career development opportunities. The students felt that these issues were biased against them and blocked their career development opportunities. 
Anastasios and George (2006) carried out a study on secondary students' attitudes and perceptions and what caught the authors' attention is the high popularity of "barman" compared to the "food server". The barman job classification ranks as the second most popular hospitality profession with almost $30 \%$, surpassed only by the hotel manager. It is the only profession ranked in the top 5 which is not at a managerial level. It seems that secondary students relate themselves with bartending due to their exposure with the particular job during their social activities. It is also important to note, that teenagers might consider bartending as an ideal job that enables them to earn money, meet interesting people, work only at night, while at the same time having fun, especially in nightclubs. In surprisingly high ranks, respondents placed the professions of chef and cruise ship manager. In recent years, chefs gained tremendous popularity due to the publicity earned from local electronic and printed media. This publicity enhanced the profession's image and reputation, thus making it a more attractive option to secondary school students. If one visualizes the chef as simply a cook, working odd hours, in a fast paced and often inhumane environment, it will be logical to shape a rather negative perception of this position. On the other hand if one gains visual awareness of the position's uniqueness, the innovation, the symphony and harmony of taste and textures, and the artistic side of the job, many might shape a much different opinion. Awareness is the key to improving individual perceptions towards a particular profession. The chef position can become the benchmark in how we could enhance the image of other hospitality professions that currently suffer from negative perception.

\section{Methodology}

The study was undertaken in Moi University, Department of Hotel and Hospitality Management, Uasin Gishu County, and Maseno University's Department of Ecotourism, Hotel and Institutional Management (ECOHIM) in Kisumu County, which has a hotel as a training unit for the student pursuing the course and it is also situated in the town centre. The two institutions were chosen in order to have captive respondents and to reduce related costs since the two are not far from one another and are also close to the researchers' area of residence. The study employed a descriptive survey research design because it was concerned with specific predictions, with narration of facts and characteristics concerning individuals, groups or situations. The researcher then identified and extracted themes from these descriptions (thematic analysis) in addition to measuring them. A mixed research approach which included qualitative and quantitative methods was employed for the study.

The target population consisted of first year and fourth year students from Moi and Maseno Universities. At the time the study was being undertaken, the total student population at Moi University pursuing Hotel and Hospitality Management was 204. Out of this, 26 were first years, 48 second years, 60 third years, and 70 fourth years. The department had 12 lecturers. At Maseno University, there was a total student population of 208. Out of this, 92 were first years, 38 second years, 38 third years and 40 fourth years. The department had 13 lecturers.

Since the sampling frame was finite $(\mathrm{N}=228)$, the following formula was employed in the calculation of the sample size. The formula is given below (Reid \& Boore, 1991).

$$
n=\frac{N}{\left[\left(1+N(e)^{2}\right]\right.}
$$

Where $\mathrm{n}=$ sample size; $\mathrm{N}=$ population size; $\mathrm{e}=$ accepted level of error taking alpha as 0.05. By substitution in the formula, we have sample size as;

$$
n=\frac{228}{[1+228(0.05) 2]}=145
$$

Thus a minimum of 145 students was included in the current study. Stratified random sampling was used in the selection of the study participants (Kothari, 2004) as the population was stratified by university (Moi and Maseno) and also by year of study (first and fourth). Student admission numbers was used to randomly pick study participants. Purposive sampling was used to select the universities. Stratification was done proportionately to the stratum size. Table 1 shows the sample size. 
Table1: Sample Size

\begin{tabular}{|c|c|c|c|}
\hline University & Target population & Sample size & Distribution of sample size \\
\hline Moi & $(96 / 228) * 145$ & 61 & 17 first years and 44 fourth years \\
\hline Maseno & $(132 / 228) * 145$ & 84 & 59 first years and 25 fourth years \\
\hline
\end{tabular}

Primary data was obtained from the questionnaires that were given to students. The respondents were asked to indicate their degree of agreement to each statement measured on a five point Likert scale ranging from "strongly disagree" (1 point) to "strongly agree" (5 points). Secondary data was obtained from various libraries, internet, various publications, newspaper articles, journals and various related books. The completed questionnaires were checked for completeness and coded. Data was entered and analyzed using SPSS Ver 25. Analysis was done using a quantitative research approach. Data was analyzed using descriptive statistics. Frequencies, means and standard deviation were used to summarize the data. Pearson correlation and regression model was used to test. Significance was set at $\alpha=0.05$.

\section{RESULTS}

\subsection{Influence of Perceived Benefits of Working in the Hospitality Industry}

With regards to influence of perceived benefits of working in the Hotel and Hospitality industry, more than half of the $1^{\text {st }}$ years agreed that a career choice in the H\&H industry is lucrative [44(62.9\%)], given another opportunity they will still choose a career in this industry [45(61.6\%)], they are likely to work in the H\&H industry after graduation [49(67.1\%)], industrial attachment boosted their career choice in the industry, their family is proud of their career choice [32(61.5\%)] and that pay for most jobs in the $\mathrm{H} \& \mathrm{H}$ industry is low [39(53.4\%)] as demonstrated Table 2.

Table2: Influence of Perceived Benefits of Working in the Hospitality Industry (N=74)

\begin{tabular}{|l|l|l|l|l|}
\hline Influence of perceived Benefits & Disagree (\%) & Neutral (\%) & Agree (\%) & Mean \pm sd \\
\hline H\&H is a respected industry to work in & $14(18.9)$ & $9(12.2)$ & $51(68.9)$ & $2.5 \pm 0.8$ \\
\hline $\begin{array}{l}\text { Have pride in my career choice within the } \\
\text { H\&H industry }\end{array}$ & $8(10.8)$ & $15(20.3)$ & $51(68.9)$ & $2.6 \pm 0.7$ \\
\hline $\begin{array}{l}\text { My character fit well with my career } \\
\text { choice within the H\&H industry }\end{array}$ & $14(18.9)$ & $9(12.2)$ & $51(68.9)$ & $2.5 \pm 0.8$ \\
\hline $\begin{array}{l}\text { I would feel like a slave if I worked in the } \\
\text { H\&H industry }\end{array}$ & $38(51.4)$ & $4(5.4)$ & $32(43.2)$ & $1.9 \pm 1.0$ \\
\hline $\begin{array}{l}\text { I would derive pleasure working in this } \\
\text { industry }\end{array}$ & $15(20.3)$ & $11(14.9)$ & $48(64.9)$ & $2.5 \pm 0.8$ \\
\hline
\end{tabular}

Responding to the same question, more than half of the $4^{\text {th }}$ years agreed that a career choice in the $\mathrm{H} \& \mathrm{H}$ industry is lucrative, 50(70.4\%); and that given another opportunity they would still choose a career in this industry, 45(64.3\%). The results also indicated that most of them are likely to work in the H\&H industry after graduation [40(59.7\%)], industrial attachment boosted their career choice in the industry, their family is proud of their career choice [50(71.4\%)] and that pay for most jobs in the $\mathrm{H} \& \mathrm{H}$ industry is low [45(64.3\%)] as illustrated in Table 3.

Table3: Influence of Perceived Benefits of Working in the Hospitality Industry $(N=71)$

\begin{tabular}{|l|l|l|l|l|}
\hline Influence of perceived Benefits & Disagree (\%) & Neutral (\%) & Agree (\%) & Mean \pm sd \\
\hline H\&H is a respected industry to work in & $9(12.9)$ & $8(11.4)$ & $53(75.7)$ & $2.6 \pm 0.7$ \\
\hline $\begin{array}{l}\text { I have pride in my career choice within the } \\
\text { H\&H industry }\end{array}$ & $11(15.7)$ & $11(15.7)$ & $48(68.6)$ & $2.5 \pm 0.8$ \\
\hline $\begin{array}{l}\text { My character fit well with my career choice } \\
\text { within the H\&H industry }\end{array}$ & $6(8.6)$ & $6(8.6)$ & $58(82.9)$ & $2.7 \pm 0.6$ \\
\hline $\begin{array}{l}\text { I would feel like a slave if i worked in the } \\
\text { H\&H industry }\end{array}$ & $47(67.1)$ & $7(10)$ & $16(22.9)$ & $1.6 \pm 0.8$ \\
\hline $\begin{array}{l}\text { I would derive pleasure working in this } \\
\text { industry }\end{array}$ & $8(11.4)$ & $10(14.3)$ & $52(74.3)$ & $2.6 \pm 0.7$ \\
\hline
\end{tabular}

To test the hypothesis "perceived benefit do not have a significant relationship with career choice of the students in the industry", the study computed the Pearson's correlation coefficient to assess the correlation between perceived benefit and career choice of the students in the industry. As shown in Table 4, from the findings, perceived benefits were shown to have a significant and positive relationship on the career choice of the students, $r=0.183, p=0.013$. 
Table4: Relationship between Perceived Benefit and with Career Choice of the Students in the Industry

\begin{tabular}{|l|l|l|l|}
\hline & & $\begin{array}{l}\text { Career choice of the students in } \\
\text { the industry }\end{array}$ & $\begin{array}{l}\text { Perceived } \\
\text { benefits }\end{array}$ \\
\hline $\begin{array}{l}\text { career choice of the students in } \\
\text { the industry }\end{array}$ & $\begin{array}{l}\text { Pearson } \\
\text { Correlation }\end{array}$ & 1 & \\
\hline & Sig. (2-tailed) & & 1 \\
\hline perceived benefit & $\begin{array}{l}\text { Pearson } \\
\text { Correlation }\end{array}$ & $0.183^{*}$ & \\
\hline & Sig. (2-tailed) & 0.013 & \\
\hline
\end{tabular}

* Correlation is significant at the 0.05 level (2-tailed).

\section{DISCUSSION}

From the results, it was established that perceived benefit had a positive and significant effect on career choice of the students in the industry $(\beta=0.013, \rho<0.05)$. Despite the positive impact of perceived benefit of the hotel and hospitality industry on career choice, work experience as a trainee, in the industry has affected students' perceptions in a negative way (Kung'u, 2011). Similarly, Kuria, Wanderi and Ondigi (2012) have observed that as students progress in their degree, their perception of the hotel and hospitality industry deteriorates. Mohammed (2018) and Li et al. (2018) have also echoed that low pay, a perceived and real lack of formal qualification at all levels has made students view the hospitality industry as unattractive.

With a majority of the $1^{\text {st }}$ years agreeing that $\mathrm{H} \& \mathrm{H}$ is a respected industry to work in, this affirms that they feel it is a respected industry to work in. The subsequent indicators on pride for the industry and character matching their career choice all had a majority score which clearly shows that the impact is positive and that there is enthusiasm to work in the industry. On feeling like a slave if at all if they worked in the industry, the responses were almost similar, between those who agreed and those who did not. Those who agreed were $43.2 \%$ while those who disagreed were at $51.4 \%$ creating a slight difference of $7 \%$. This means they already know what goes on in the industry as far as being submissive and subjective to customer and bosses are concerned. Being a group of students who have not been on attachment, it may be said that these are observations they have noted when they visit hotels and other hospitality establishments. This is an important factor since it has been pointed out by researchers such as ChooiHwa et al. (2010), who term it as emotional labour, which is one of the indicators that deter these graduates from seeking employment in the industry after graduation. Majority of the students $64.9 \%$ agreed that they would derive pleasure working in the industry and this goes to affirm that except for a few factors like the emotional labour mentioned above and low pay, once more the impact remains positive.

It is noteworthy that the fourth years are now exiting into the industry. This is a group of students who have interacted well with the course and have been exposed to the industry twice through industrial attachment. During their training, they have also been taught various issues concerning the industry and it now assumed that they have made a decision to either work in the industry or not to work after their graduation. When asked if the $\mathrm{H} \& \mathrm{H}$ industry is a respected industry to work in, many $(75.7 \%)$ agreed that it is. This helps to justify the fact that majority of them agreed that they would work in the industry after graduation. Pride and character go hand in hand and when one has pride in their work it means they derive pleasure in what they are doing. So when many of the students agree that they have pride in their career choice, $(68.6 \%)$ and that their character fits well with their career $(82.9 \%)$, it shows course why they would derive pleasure working in the industry. Since the hospitality industry depends largely on human interaction, these humans play a pivotal role in delivering a product. Therefore this goes on to say that one has to derive pleasure and have a personality that would fit in well with the requirements of the industry, which the results of this study is agreeing to.

When asked if they would feel like slaves working in this industry, again, majority refuted $(67.1 \%)$. This would be attributed to the fact that answering in the affirmative depicts negativity which they think would ruin the results. Studies have shown that the hotel industry bears a lot of emotional labour (ChooiHwa et al., 2010) which meant the performance of various tasks in the hotel bears a lot of emotions in the context of paid employment. So if they have pleasure in their work as earlier indicated, it would mean carrying out their duties well and coping with the intrigues of emotional labour. 


\section{CONCLUSION AND RECOMMENDATIONS}

The discussions in this paper have demonstrated that personal interests play a pivotal role in attitude formation. From the responses received, most students agreed that the H\&H industry is a reputable industry to work in and they would find pride and not feel ashamed or like slaves if they worked in the industry. This coupled with the fact that their characters fit well with the responsibilities expected of them while working in the industry indicate that they have a purpose, they would want to work, earn a living and meet their financial obligations. It is the researcher's opinion that this may work out for a while considering that they are looking forward to earn a living after studies. But as they grow and become more experienced, their enthusiasm may fade off. This is because their financial obligations may increase considering that they may be starting families of their own or they may want to have more money at their disposal. The social cognitive career theory (SCCT) emphasizes on several cognitive variables including self-efficacy where one believes in themselves to perform given tasks well anticipating a reward in form of salary or otherwise. If they feel that the reward being given does not match performance then they are likely to stop and look elsewhere for better opportunities.

This paper thus recommends that attention should be given to students who have less interest and may also be harbouring a negative attitude about the industry. Career guidance and counselling may be offered to individual students so that they do not impact others with this negative attitude which may have detrimental effects. This kind of attitude should be nabbed in the bud and sustained throughout their four-year training. Educators should communicate the benefits of working in the industry and career possibilities in the hospitality industries and companies to students. They should make them aware about mobility progression, job diversity in the industry and other career information in order to create greater student interest about careers in the industry. Indeed knowledge of career identity and long term career planning will better enable students establish realistic and suitable career expectations.

\section{REFERENCES}

[1] Abdullah, R., Zahari, H., Mat, N. A. N., Zain, R. A., \& Derani, N. (2015). Hospitality Internships: An Employment Advantage or Perilous Experience. Journal of Basic and Applied Scientific Research, 5(8), 34-38.

[2] Anastasios, Z., \& George, K. (2006). Perceptions and Attitudes Towards the Hospitality Profession in Cyprus. Management, 17(5), 436-447.

[3] Brown, E. A., Arendt, S.W., \& Bosselman, R. H. (2014). Hospitality Management Graduates' Perceptions of Career Factor Importance and Career Factor Experience. International Journal of Hospitality Management, 37, 58-67.

[4] Chang, S., Walsh, K., \& Tse, E. C. Y. (2014). Understanding Students' Intentions to Join the Hotel Industry: The Role of Emotional Intelligence, Service Orientation, and Industry Satisfaction. Cornell Hotel Quarterly, 56(4), 369-382.

[5] Chellen, H., \& Nunkoo, R. (2010). Understanding Students' Commitment to Employment in the Tourism and Hospitality Industry. Paper presented at the International Research Symposium in Service Management, Mauritius.

[6] ChooiHwa, A. M., Supinah, R., Japang, M., Rosie, C., \& Nasah, J. (2010). Service with a Smile: Human Resource Perspective of Emotional labour. Labuan e-Journal of Muamalat and Society, 4, 26-33.

[7] Ghalandari, K., Jogh, M. G. G., Imani, M., \& Nia, L. B. (2012). The Effect of Emotional Labour Strategies on Employees Job Performance and Organizational Commitment in Hospital Sector: Moderating Role of Emotional Intelligence in Iran. World Applied Sciences Journal, 17(3), 319-326.

[8] Hill, A P. (2013). Motivation and University Experience in First-Year University Students: A SelfDetermination Theory Perspective. Journal of Hospitality, Leisure, Sport \& Tourism Education, 13, $244-254$.

[9] Jayaweera, T. (2015). Impact of Work Environmental Factors on Job Performance, Mediating Role of Work Motivation: A Study of Hotel Sector in England. International Journal of Business and Management, 10(3), 271-278.

[10] Jiang, B., \& Tribe, J. (2009). Tourism Jobs - Short Lived Professions': Student Attitudes towards Tourism Careers in China. Journal of Hospitality, Leisure, Sport and Tourism Education, 8(1), 4-19.

[11] Kim, B., McCleary, K. W., \& Kaufman, T. (2010). The New Generation in the Industry: Hospitality/Tourism Students' Career Preferences, Sources of Influence and Career Choice Factors. Journal of Hospitality \& Tourism Education, 22(3), 5-11.

[12] Kothari, C. R. (2004). Research Methodology: Methods and Techniques (2 ${ }^{\text {nd }}$ Ed.). New Delhi: New Age International Publishers. 
[13] Kung'u, S. K. (2011). Assessment of the Labour Turnover and Wastage Levels in Three to Five Star-Rated Hotels in Nairobi, Kenya. Unpublished MSc Thesis, Kenyatta University, Nairobi.

[14] Kuria, K. S., Wanderi, M. P., \& Ondigi, A. (2012). Hotel Employment in Kenya: Contingent Work or Professional Career? International Journal of Academic Research in Business and Social Sciences, 2(7), 394-404.

[15] Li, J., Canziani, B. F., \& Barbieri, C. (2018). Emotional labour in Hospitality: Positive Affective Displays in Service Encounters. Tourism and Hospitality Research, 18(2), 242-253.

[16] Meliou, E., \& Maroudas, L. (2011). Career Development in the Hospitality Industry in Greece: Implications for Human Resource Practices. Journal of Human Resources in Hospitality \& Tourism, 10, 218-233. 10.1

[17] Mohammed, A. M. (2018). Students' Intention to Join the Hotel Industry in Malaysia: The Role of Physical Working Conditions, Pay and Benefits, and Promotion Opportunities. Journal of Business and Retail Management Research (JBRMR), 12(4), 240-245.

[18] Reid, N. G., \& Boore, J. R. (1991). Research Method and Statistics in Health Care. London: Edward Arnold.

[19] Richardson, S. (2008). Undergraduate Tourism and Hospitality Students Attitudes toward a Career in the Industry: A Preliminary Investigation. Journal of Teaching in Travel \& Tourism, 8(1), 23-46.

[20] Richardson, S. (2010). Tourism and Hospitality Students' Perceptions of a Career in the Industry: A Comparison of Domestic (Australian) Students and International Students Studying in Australia. Journal of Hospitality and Tourism Management, 17(1), 1-11.

[21] Roney, S. A., \& Öztin, P. (2007). Career Perceptions of Undergraduate Tourism Students : A Case Study in Turkey. Journal of Hospitality, Leisure, Sport and Tourism Education, 6(1), 4 - 18.

[22] Whitelaw, P. A., Barron, P., Buultjens, J., Cairncross, G., \& Davidson, M. (2009). Training Needs for the Hospitality Industry. Sydney: Sustainable Tourism Pty Ltd.

[23] Yin, C. (2014). Review of Studies on Luxury Hotels over the Past Two Decades. Unpublished MSc Thesis, Iowa State University, Ames, Iowa.

Citation: Ruth Adhoch. "Perceived Benefits and Making a Career Choice in the Hospitality Industry: Is it Worth it? ". International Journal of Research in Tourism and Hospitality (IJRTH), vol 5, no. 3, 2019, pp. 2633. doi: http://dx.doi.org/10.20431/2455-0043.0503003.

Copyright: (C) 2019 Authors. This is an open-access article distributed under the terms of the Creative Commons Attribution License, which permits unrestricted use, distribution, and reproduction in any medium, provided the original author and source are credited. 